\title{
STILISTIESE ANALISE VAN NUWE-TESTAMENTIESE TEKSTE
}

L. Floor

Departement Nuwe Testamentiese Vakke, PU vir CHO

\section{ABSTRACT}

All too often literary structures in the New Testament are passed off in scholarly literature as mere literary niceties serving only aesthetic ends. Too little consideration has been given to the possible exegetical significance of such structures to the interpretation of biblical texts. This article is an attempt to present an apologetic for the value of stylistic analysis of New Testament texts as an aid in interpreting the New Testament. It must be kept in mind that to the biblical authors, artistry in the use of stylistic structures was not an end in itself, but a means towards more effective communication of the message.

\section{WOORD VOORAF}

Ek moet allereers $u$ aandag vra vir die formulering van die titel van $\mathrm{my}$ artikel. Hierdie titel wat as ' $n$ opdrag na $m y$ toe gekom het, praat van 'n stilistiese analise van Nuwe-Testamentiese tekste. Dit hou al dadelik 'n beperking in. Dit sal dus nie gaan oor sintaktiese ontleding, semantiese analise of redevoeringanalise nie, hoewel dit natuurlik 'n vraag bly of die een sonder die ander gedoen kan word.

Daar is ' $n$ ou distichon, ' $n$ Latynse strofe van twee reëls wat bestaan uit ' $n$ hexameter en ' $n$ pentameter, wat vir ons wil leer waarop die leser moet let wanneer hy $n$ teks wil lees en verklaar:

Quis scopus impellens sedes tempusque

Ft modus, haec septem scriptura altendito lector.

Die leser van 'n teks moet op hierdie sewe sake let:

$$
-369 \text { - }
$$


wie, doel, aanleiding, verband, tyd, plek en wyse.

Ook die modus, die manier, die wyse waarop 'n teks tot ons kom, is vir die analise van die teks belangrik. Die modus bring ons dus by styl, stilistiek en stilistiese analise. Daar is natuurlik al die eeue deur aandag gegee aan styl en daar is reeds baie geskryf oor stilistiek. Dit is byvoorbeeld vir iemand met in redelike kennis van 'n taal gemaklik om 'n stylfiguur te identifiseer. 'n Student in Grieks of in die Nuwe Testament sal sonder veel moeite 'n parallelisme raaksien. Maar om die funksie van so 'n stylfiguur in die betrokke konteks te omskryf is nie so gemaklik nie. Dit bring ons by die allerbelangrikste vraag na die waarde, die sinvolheid van stilistiese analise. Kan stilistiese analise van Nuwe-Testamentiese tekste werklik 'n bydrae lewer tot 'n beter verstaan van die Nuwe Testament? Anders geformuleer: het stilistiese analise betekenis vir die eksegese van die teks?

Op hierdie vraag word sowel positief as negatief geantwoord. Laat ons eers luister na 'n negatiewe reaksie. 'n Man soos Lloyd-Jones, wat in sy geskrifte wel terdeë aandag gegee het aan styl en met name aan die styl van die apostel Paulus, vra by sy bespreking van Paulus se parentesis in Rom 5:15-17: "Is this bad literary style? It is, but the Apostle frequently forgot all about style. Thank God that he did! Style has almost killed the Christian Church and her message, it seems to me" (1976:186). Lloyd-Jones is van oordeel dat stilistiese analise van die Bybelse boodskap die kerk geen goed gedoen het nie. Die prediking het daardeur skade gely. "The manner became more important than the matter, the style mattered more than the substance" (1976:186). Daar is natuurlik die gevaar dat die vorm belangriker geag word as die inhoud. Tereg skrywe Nida et al.: "For some persons it is better to be able to admire the style while forgetting the message" (1983:166).

Josef Zmijewski, daarenteen, is baie positief oor stilistiese analise. Hierdie metode, mits goed aangewend "erweist sich damit als wertvolle Hilfe für die inhaltlich-theologische Untersuchung des Textes" (1978: 139).

2. WAT IS STYL? 
Alvorens ons gaan praat oor die nut, die waarde en die betekenis van stilistiese analise, moet ons eers vra: wat is styl presies? Dit lyk of styl so onbegrypbaar en so ondefinieerbaar is scos die geur van 'n blom, die boeket van wyn, die smaak van kos of die klank van musiek. Daar kom nog dit by dat styl nie maar net 'n eienskap van taal is nie. Ons praat van die boustyl, haarstyl, musiekstyl, kledingstyl, lewenstyl ensovoort.

Ons moet ons tot die styl van taal beperk, maar wie probeer om dan die styl van taal te omskryf, kry die gevoel dat hy besig is om die ongrypbare te wil gryp, die ondefinieerbare te wil definieer. Hier lê die oorsaak dat daar so baie pogings aangewend is on aan te dui wat styl presies is. Daar is in hele katalogus van styldefinisies beskikbaar. J.W.H. Atkins gee in die eerste deel van sy literary crjticism in Antiquity (1952) ' $n$ mooi oorsig van die pogings wat deur die ou Grieke aangewend is om styl te omskryf. Isocrates noem styl die spesifieke gebruik van taalkarakters. Plato is weer van oordeel dat styl ook die karakter van die spreker of skrywer reflekteer. Vir Aristoteles is styl weer die kuns van komposisie, van samestelling. Hy oordeel ook dat styl die emosionele karakter van 'n geskrif aandui.

Dit is ' $n$ groot warheid dat styl nie van iemand se persoonlikheid losgemakk kan word nie. Almal is dit eens dat daar 'n bepaalde verhouding bestaan tussen iemand se taalgebruik en sy persoonlikheid. Buffon het gese: "Style is the man himself" (vgl. Ullmann, 1973:64). Op ' $n$ konferensie oor 'Style in Language' in die VSA het Roger Brown die bewering gemaak "that the style of a person is as unique as his finger prints" (1968:378), natuurlik met hierdie verskil dat jou vingerafdrukke altyd dieselfde bly, terwyl jou styl kan verander. Proust het die opmerking gemaak dat styl vir 'n skrywer is wat kleur is vir 'n skilder (vgl. Ullmann, 1973:40). Volgens T.A. van Dijk kom 'n mens met styl by die psige van die skrywer en daarom moet styl in die eerste plek psigologies benader word $(1980: 2)$.

J.P. Louw is van oordeel dat styl te doen het met die taalkundige inkleding van 'n toespraak. 
Zmijewski noem nie minder as sewe verskillende definisies van styl nie en dan kom hy ook nog met 'n eie voorstel (1978:40-48).

Hoe moeilik dit is om styl presies te definieer, blyk reeds uit Demetrius se beroemde werk oor styl. In sy boek Peri Hermeneias soek 'n mens tevergeefs na 'n afgeronde definisie van styl. Pleks van om styl te definieer, kom hy tot vier hoofelemente of kwalifikasies van styl, die sogenaamde charaktēres (Grube, 1981:24,25; Schenkeveld, 1964:11). Die vier basiese stylsoorte is: eenvoudige styl, kragtige styl, uitgebreide styl en elegante styl. Elke styl analiseer Demetrius dan weer onder drie aspekte: "diction or the choice of words, composition or the arrangement of words, and subject-matter" (Grube, 1961:25). Ook in die bekende boek Style and Discourse het E.A. Nida et al. nie probeer om 'n definisie van styl te gee nie (vgl. Snyman, 1984:95).

Een ding is wel duidelik dat styl nie net te doen het met indiwiduele woorde en frases nie, maar dat styl betrekking het op "a longer stretch of language such as the paragraph, and for this matter, even the total discourse" (Louw, 1985:171). Styl het sowel betrekking op die rangskikking van woorde as op die gedagte.

\section{STILISTIESE ANALISE}

Wanneer dit al so moeilik is om styl presies te definieer, wat sal ons dan maak met stilistiese analise? Hoe kan iets wat al moeilik is om te definieer, geanaliseer word? Die geskiedenis van die stilistiek is daar weer om te bewys dat daar oor stilistiese analise nie eenders gedink word nie.

Wanneer iemand 'n teks stilisties wil analiseer dan duik die vraag dadelik op, op watter vlak mot hy met sy analise begin, en 'n vraag wat dan weer daarop volg, sal lui: kan stilistiese analise wel tot een vlak van taal beperk word? Wanneer styl sowel betrekking het op woorde as op die gedagte, dan beteken dit dat styl vanuit sowel die sintaktiese hook as uit die semantiese hoek benader moet word.

N. Turner in deel IV van J.H. Moulton se A Grammar of New Testament Greek soek styl veral op die vlak van die sintaksis: "Style in our view, involves the same considerations as syntax" (1976:1). Ander, 
daarenteen, beskryf styl weer as 'n afwyking van vasgestelde sintaksiese reëls (vgl. Snyman, 1982:1,2).

J.P. Louw beskou styl basies as 'n semantiese faktor (1975:101). Halliday en Hasan onderskei drie vlakke, drie kodifiseringsvlakke of strata in taal, naamlik die semantiese (betekenis), die leksikaal-grammatiese (vorm) en die fonologiese (uitdrukking) en dan soek hulle styl in die semantiese sisteem van taal soos gerealiseer deur die grammatikaal-leksikale sisteem $(1976: 36)$.

In die diskussie oor stilistiese analise kom telkens weer die verhouding van styl tot retoriek ter sprake. Ongetwyfeld is styl en retoriek nou met mekaar verwant. Vir die Grieke was dit baie belangrik om in enige vorm van die geskrewe taal uiting te gee aan die styl. Retoriek was 'n belangrike vak in die opvoeding van die jeug, en kennis van die retorika is altyd beskou as die mees kenmerkende eienskap van 'n goed opgevoede mens (Louw, 1982:5; Clark, 1959:viii). In die Oudheid is daar veral gekyk na die styl van die redenaar. Demetrius, byvoorbeeld, het tot die retoriese tradisie behoort en nie tot die wysgerige nie (Grube, $1961: 22$ )

Hoewel retoriek en styl nou aan mekaar verwant is, moet ons tog die onderskeid ook goed raaksien. Retoriek is die omvattende. Dit het te doen met die verdeling van 'n toespraak in die inleiding, die stel van die saak, die bewysvoering en die konklusie, terwyl styl te doen het met die taalkundige inkleding van die toespraak. "Rhetoric is that aspect of ancient education which provided the general modes of expression, style is the practical technique in composing an expression in language. Rhetoric is the cechne as such, style is the laxis, the frasis" (Louw, 1982:6).

Tot vandag toe is die stryd oor die verhouding tussen retoriek en stilistiek nog nie uitgewoed nie. J.P. Louw het daarop gewys dat in baie groter grammatikas stilistiek net as 'n aanhangsel beskou word en slegs 'n beskeie plek kry, terwyl hy van oordeel is dat stilistiek die sine qua non vir die retorika is $(1975: 100)$. Soos hy styl basies in semantiese faktor genoem het, so beskou hy die retorika in sy wese ook as ' $n$ semantiese bedryf. "Immers die retorika het geheel en al te doen met 
die wyse waarop iets gesé word en dit is niks anders as die proses van transformasies wat op sy beurt so 'n groot rol in die semantiek speel nie, want transformasies behels die verskeidenheid van opperviakte-strukture wat vir dieselfde diepte-struktuur aangewend kan word. So is sinne soos 'sy sing mooi' en 'haar sang is mooi' twee oppervlakte-strukture wat feitlik dieselfde betekenis het want die basiese gegewens van die segginge is dieselfde - hulle het dus dieselfde diepte-struktuur" (Louw, 1975:101).

In die bekende boek Style and Discourse het E. A. Nida et al. indringend aandag gegee aan die verhouding tot styl en retoriek. In 'n belangrike opgepubliseerde artikel A Semiotic Approach to Rhetoric het Nida reeds sy insigte oor die verhouding tussen retoriek en stilistiek bekend gemaak en in die boek style and Discourse word daarby aangesluit.

Die skrywers is van oordeel dat in die verlede sekere basiese oorwegings in die benadering tot styl en retoriek nie in ag geneem is nie. Daar is volgens die skrywers meer funksies van retoriese eienskappe as wat tradisioneel besef is. Om hierdie funksies raak te sien moet daar 'n onderskeid gemaak word tussen die makrovlak en die mikrovlak van retoriek (1983:11). Die makrovlak van retoriese struktuur het te doen met die groter eenhede wat gewoonlik semanties met mekar verband hou, terwyl die mikrovlak beskou kan word as ' $n$ sin wat rondom ' $n$ kerndeel of nukleus ontwikkel het (Snyman, 1982:2,5). Wanneer die onderskeid tussen makrovlak en mikrovlak goed in die oog gehou word, kan dit help om retoriese eienskappe en funksies volgens ' $n$ bepaalde sisteem aan te tson. Daar kom egter nog iets by. Stilistiese analise kan nie gedoen word wanneer daar nie aandag gegee word aan drie belangrike verhoudings nie, naamlik: die verhouding tussen redevoering en bedoeling, tussen redevoering en die werklikheid en tussen redevoering en die reaksie van die reseptor (Nida et al., 1983:11). Daar moet weggebreek word van die gedagte dat die styl, die retoriese met iets oor die vorm, die estetiese te sè het, maar daar moet gesoek word na die funksie van die styl en die retoriek. Botha is van oordeel dat stylfunksie vroeër waarskynlik nie in 'n semiotiese sin gesien is nie. Mense het aan betekenis slegs gedink in terme van leksikale eenhede. Dat retoriese eienskappe as tekens wat betekenis het vir die reseptor, is nie raak gesien nie (Botha, 1984:5). 
In hierdie metode van stilistiese analise waar daar dus gesoek word na die funksie van styl en retoriek, word eers gekyk na die wyse waarop begrippe en gedagtes in 'n redevoering georden word. Hierdie ordening van begrippe en gedagtes word dan op twee vlakke ondersoek, naamlik die makrovlak en die mikrovlak (Nida et al., 1983:12). Soos reeds gestel die makrovlak van retoriese struktuur het te doen met die groter eenhede wat gewoonlik semanties met mekaar verband hou, terwyl retoriese merkers op die mikrovlak dien om die verband tussen die eenhede op die makrovlak te versterk en die impak (trefkrag) en appèl (aantrekkingskrag) daarvan deur verskeie formele tegnieke te verhoog (Botha, 1984:11).

Op die makrovlak is daar twee elemente wat 'n groot rol speel en waaraan aandag by die stilistiese analise gegee moet word, naamlik progressie of voortgang, en kohesie of samehang. Die progressie hang saam met die verskeidenheid en die kohesie met die eenheid van die diskoers (Snyman, $1982: 2$; Nida et al: $1983: 12$ )

Op die mikrovlak is daar ander retoriese prosesse waraan by stilistiese analise aandag gegee moet word. Daar moet gelet word op herhaling. weglating, ' $n$ skuif in verwagtinge, die afmeting van eenhede en kongruensie (Snyman, 1982:7; Nida et al., 1983: 188-190)).

Tegnies word hierdie metode van stilistiese analise soos volg uitgevoer: die sinne word opgebreek in hul nukluère strukture, wat onder mekaar neergeskryf word (Snyman, 1982:13). Dit herinner sterk aan J.C. Coetzee se metode van gedagtestruktuurontleding.

Vervolgens word die progressie beskryf in terme van die logiese relasies tussen die nukluére strukture en dan word gekyk na die kohesie van die diskoers deur te let op die tematiese eenheid. Daarna word na die inikrovlak beweeg en dan word gelet op die wyse warop die retoriese merkers op die mikrovlak die trefkrag of die aantrekkingsvlak op die makrovlak verhoog (Snyman, 1982:13,14).

Om nou die betekenisse van die retoriese tegnieke te bepaal word in die eerste plek gebruik gemaak van in breër raamwerk van moderne literère analise warin retoriese tegnieke bestudeer word in terme van hulle 375- 
semiotiese betekenis. Maar in die tweede plek word ook gebruik gemaak van die beskrywing van retoriese beginsels en hulle effek tydens die Hellenistiese periode. Hierdie beginsels is gereflekteer in die teoretiese geskrifte van Dematrius, die (Auctor) ad Iteremium, Longinus en andere en is $n$ belangrike aanduiding van hoe die retoriese tegnieke in die geskrifte van die Hellenistiese periode funksioneer het (Snyman, 1984:100). In 'n aanhangsel in die boek styje and Discourse het Snyman en Cronje selfs alle stylfigure geklasifiseer volgens die beginsel van herhaling, weglating en skuif in verwagting (Nida et al., 1983:172-191). Alle stylfigure wat ons vroeër by die studie van klassieke Grieks geleer het, verskyn hier weer op die toneel.

Wanneer ons na die resultate van hierdie stilistiese analise kyk, sal ons ontdek dat hulle inet betrekking tot die verklaring van die teks nie veel verskil van wat ook in kommentare te vinde is nie (vgl. Nida et al., 1983:110-144). In sy uitvoerige en ingewikkelde stilistiese analise van 1 Kor 13 kom A.H. Snyman tot die konklusie dat die skrywer van hierdie lied beoog:

- om saam te bind

- om 'n aangename effek te gee

- on te oortuig (Snyman, 1982:23).

In sy analise van $\operatorname{Rm} 8: 31-39$ is die resultaat dat die verskillende retoriese tegnicke enige of al die volgende betekenisse sein:

- 'n assosiasie vall die skrywer met sy leser

- spanning

- emosie

- oorreding (Snyman, 1984:102)

Die vraag kan gevra word of so 'n ingewikkelde tegniese analise noodsaaklik is om tol hierdie stilistiese resultate te kom. 
In die algemeen kan van hierdie stilistiese analise twee dinge gesê word; iets positief en iets negatiefs. Wat die positiewe betref: dit moet sonder enige twyfel hoog gewaardeer word dat die ontwerpers van hierdie metode van stilistiese analise binne die semiotiese verwysingsraamwerk in onderskeid maak tussen drie relasies in taal, te wete die "discourse to intent, discourse to the real world, and discourse to the response of receptors" (Nida et al., 1983:11).

Wat die negatiewe betref is dit 'n basiese fout om sonder enige bewys te veronderstel dat daar in verband is tussen, en selfs in bewuste afhanklikheid van die retorici van die Grieks-Romeinse wereld by die skrywers van die Nuwe Testament (Nida et al., 1983:9). Dit mag wees dat Paulus en ook die skrywer van die brief aan die Hebreërs en miskien selfs Lukas enige kennis van heidense outeurs gehad het, maar dit is moeilik om in te sien dat byvoorbeeld Markus of Johannes bewus was van 'n akademiese analise van die retoriek (vgl. Taber, 1985:143).

In die laaste tyd word die invloed van die retorika op Paulus se briewe met hernude ywer bestudeer. H.D. Betz (1974:353-379) het Paulus se brief aan die Galasiërs ondersoek op basis van die antieke forensiese retoriek. Hy is oortuig dat die stylkonvensies van die antieke brief en die beginsels van die retoriek ' $n$ invloed uitgeoefen het op die wyse waarop die brief aan die Galasiërs opgebou is. F.F. Church (1978:18-19) het op sy beurt probeer aantoon dat dit eerder die sogenaamde deliberatiewe retoriek is wat Paulus suksesvol gebruik het. Hy vind dit met name ten opsigte van Paulus se brief aan Filemon. Die deliberatiewe retoriek kan saamvattend só beskryf word: die funksie daarvan is om tot aksie op te roep of on daarvan af te raai. Dit is veral deur ' $n$ beroep op die eergevoel (homestas) en op die voordepl (utilltas) wat in handeling inhou dat die angesprokene tot aksie beweeg wil word. $\mathrm{Om}$ so "n aksie tot stand te bring word gesteun op drie bewyse (pistis): die cthos of mores, die pathos of adfoctus en die logos. Die etlins het te doen met die goeie karakter van die spreker, die pathos met die hoorder wat in die regte gemnedstemming gebring moet word en die Ingos het te doen met die toespraak self, naanlik na die mate waarin dit die bewys lewer of oënskynlik lewer (Kennedy, 1963:203-206). Daar word dus op drie vlakke beweeg om 'n saak te bewys: op din vlak van die eliese, die emosionele ell die redelike. 
Dit is baie moeilik om na te gaan of die styl van die skrywers van die Nuwe Testament en dan met name dié van Paulus hierdie invloed ondergaan het. Betz gee self toe dat Paulus dikwels van die gebruiklike konvensies afwyk en 'n eie koers volg. Tereg het B.C. Lategan opgemerk dat die gevaar bestaan dat die aandag van die teks na die skrywer agter die teks en sy (vermeende) gemoedstoestand en bedoelinge verskuif kan word (Lategan, 1984:111).

\section{DIE STYL VAN GRIEKS IN DIE NUWE TESTAMENT}

Wanneer ons vervolgens ' $n$ blik slaan in verskillende grammatikas van die Nuwe-Testamentiese Grieks, dan sal ons ontdek dat elkeen sy eie opinie gee oor die styl van die Nuwe-Testamentiese skrywers. Die bekende Graminar of New Testament Greek wat vir die eerste keer in 1906 gepubliseer is, het ' $n$ volledige volume aan styl gewy. Nigel Turner, wat ook die derde deel oor sintaksis geskryf het, is die skrywer van die vierde deel oor styl. Ons het hom reeds hoor sé dat volgens sy oortuiging daar nie 'n groot verskil tussen styl en sintaksis is nie. Hy spits hom in sy analise van die styl van die Nuwe-Testamentiese skrywers dan ook veral toe op "grammatical and other linguistic features which distinguish the work of one author from that of another" (Turner, 1976:1).

Hoewel A.H. Snyman self gebruik maak van die breër raamwerk van moderne literère analise warin retoriese tegnieke in terme van hulle semiotiese betekenis bestudeer word, is daar volgens hom tog nog sekere vrae wat nog beantwoord moet word. In die eerste plek vra hy of dit korrek is om gebruik te mak van die gegewens van Hellenistiese teoretici en van moderne literere analiste om die betekenis van retoriese tegnieke in antieke tekste te bepaal. Wanneer die hierbo geformuleerde vraag met 'n ja beantwoord kan word, dan bly daar tog nog ' $n$ tweede vraag oor, naamlik of ons moet probeer om die universele retoriese tegnieke met hulle betekenisse te identifiseer, warby dan 'n derde vraag opduik, te wete of die retoriese tegnieke moontlik taalspesifiek is, terwyl die betekenisse universeel is. Snyman het wel die indruk gekry dat sommige tegnieke en betekenisse soos hy dit ontleed het, universeel is, maar hy erken dat dit getoets sal moet word deur 'n omvattende vergelykende studie van styl en betekenis in antieke en moderne tekste (Snyman, 1981:102) 
Dit is die rede dat die massa materiaal wat Turner in deel IV van Moulton se grammatika aanbied vernaamlik betrekking het op woordorde, retoriek, parallelismes en parentesis, terwyl afwykinge in sinskonstruksies dikwels gesien word as die gevolg van Semitiese invloed. Turner probeer ook ondersoek op watter wyse die dialek of variëteit in die gebruik van Grieks onderskei moet word van die hoofstroom van die taal. Turner sien orals in die Grieks van die Nuwe Testament direkte Aramese en Hebreeuse invloede tesane met die sinagoge en die Septuagint. lloewel die Bybelskrywers onderling van mekaar ten opsigte van styl verskil, is Turner oortuig dat alle style in die Nuwe Testament die innerlike homogeniteit van Bybelse Grieks vertoon (1976:2)

Wanneer Turner alle skrywers van die Nuwe Testament die revue laat passeer, dan kyk hy veral na die gobruik van voornaamwoorde, partikels, konjunksies, negatiewe, preposisies en prolepsis van die subjek in 'n ondergeskikte sin. Styl het volgens Turner betrekking op die manier waarop 'n skrywer die dinge sè. Sy konklusie is: die styl van die Bybelskrywers is nie so uiteenkopend dat die eenheid van styl in die Nuwe Testament aangetas word nie (1976:2)

Die beroemde grammatika van Funk-Rehkopf se uitgawe van 1976, die welbekende Blass-Debrunner, gee in sy laaste vier hoofstukke breedvoerig andag aan die styl van die skrywers van die Nuwe Testament. In hierdie grammatika word gewys op die struktuur van die sin, woord- en sinsorde, op ellips, bragilogie en pleonasme en op retoriese figure. Die ou klassieke onderskeiding tussen die schemata lexeos (Figuren des Ausdrucks, $\varepsilon \varepsilon$, 495-496) en die sclicmala dianoias (Figuren des Gedankens, $\varepsilon \varepsilon$ 495-496) kom in hierdie boek terug, hoewel dit nog '" vraag is of hierdie onderskeiding op die skrywers van die Nuwe Testament toegepas kan word.

Ook hier duik weer die vraag op of daar tog nie iewers 'n verbindingskakel te vind is tussen die styl van die klassieke en die styl van die Nuwe-Testamentiese skrywers nie. Kan dic papiri miskien so 'n brug vorm? L. Rademacher het in sy Neutestament lichre Grammatik (1911) reeds die aandag daarop gevestig dat daar in die papiri duidelike tekens is van aangeleerde en kunsmatige rangskikkingspatrone wat wys op nabootsing van een of ander styl (1911:1). Die taalgebruik van die 
klassieke skrywers en die retoriek is nageboots. G.J.C. Jordaan oordeel dat die ooglopende mimesis van die klassieke stylfigure, waaraan die meeste Hellenistiese skrywers hulle skuldig gemaak het, in 'n minder mate by die skrywers van die Nuwe Testament aanwesig is (1978:65).

Hier duik dan weer die ou probleem op en moet ons 'n antwoord soek op die onontwykbare vraag: is daar in die Nuwe Testament sprake van retoriek? Turner is van oordeel dat daar in die Nuwe Testament geen retoriek te vinde is nie $(1976: 2)$, terwyl J.P. Louw meen dat daar wel verskynsels van die klassieke prosakuns in die Nuwe Testament voorkom, ook al is dit in ' $n$ ander vorm gegiet $(1967: 6)$. Hy is van oordeel dat die Ou-Testamentiese literatuur 'n verrykende invloed op die styl van die Nuwe-Testamentiese skrywers gehad het. Die Nuwe Testament is in Grieks geskrywe en baie stylfynighede le uiteraard in die struktuur van die Griekse taal (Louw, 1967:8). Louw waarsku dat daar nie jag gemaak moet word op die retoriese struktuur in die Nuwe Testament nie, maar dat ons dit andersyds ook nie moet ignoreer nie (Louw, 1967:8).

Ook Jordaan het gevind dat die meeste stylfigure in die Nuwe Testament in ' $n$ inindere of meerdere mate in die klassieke prosakuns aanwesig is, hoewel sommige stylfigure soos aanhalings uit die Ou Testament, eie is aan die Nuwe Testament (Jordaan, 1978:66)

\section{STILISTIESE ANALISE VAN DIE NUWE TESTAMENT}

By stilistiese analise van Nuwe-Testamentiese lekste bly dit nog maar altyd belangrik om in die eerste plek op stylfigure te let. Styl is gestruktureer. Waar styl tot uitdrukking kom, daar neem dit 'n bepaalde vorm aan.

Dit is ongetwyfeld die groot warde van die boek van E.A. Nida at al.: Style and Discourse dat daarin weer by vernuwing aandag gevra is vir styl. Die nuwe klasifikasie van stylfigure in die Grieks van die Nuwe Testament deur Snyman en Cronje in samewerking met Nida en Louw moet onk as besonder waardevol beskou word (vgl. Nida et al: 1983:22 nota 9; 172-191). 
Of hiermee saam die metodiek waarmee verskillende retoriese funksies onderskei word ook vir die analise van die styl van Nuwe-Testamentiese tekste van waarde is, moet nog bewys word. Dit bly nog in vraag of die belangrikste retoriese prosesse op die mikrovlak en die makrovlak van retoriese struktuur wetenskaplik korrek geïdentifiseer kan word. Op hierdie terrein is nog baie navorsingswerk nodig. Die semantiese studie van die antieke retoriek het nog skaars begin (Louw, 1975:108). Dit is opvallend dat Louw tydens die kongres van die NTWSA te Bloemfontein in 1985 in sy referaat: "On Johannine style" nie van die metode wat hy in sy boek saam met Nida gepropageer het, gebruik gemaak het nie.

Hoewel dit belangrik is om by stilistiese analise aandag aan stylfigure te gee, is dit tog goed om na die warskuwing van Schwyzer te luister om by die analise van 'n teks nie te gou daarin 'n stylfiguur te wil sien nie (Schwyzer, 1950:697). Ook Jordaan wys op die gevaar om met name in historiese gedeeltes van die Nuwe Testament te oorgretig na stylfigure te gaan soek. In dialooggedeeltes van die Nuwe Testament kom stylfigure meer algemeen voor (Jordaan, 1978:70).

Wanneer by stilistiese analise van Nuwe-Testamentiese tekste stylfigure gevind word, dan is dit natuurlik nie voldoende om daarby te bly staan nie. Daar moet ook op die semantiese relevansie van so $n$ stylfiguur gewys word (Louw, 1975:103). Om die betekenis van 'n stylfiguur te kan verstaan, moet op die hele perikoop, die hele redevoering waarin die stylfiguur voorkom, gelet word. Gedagtestruktuurontleding of redevoeringsanalise het immers ten doel om die kern van die semantiese gegewens uit te lig.

By die analise van stylfigure speel woordorde ook 'n belangrike rol. Al erken Blass-Debrunner dat Griekse woordorde baie vryer is as woordorde in moderne tale, is daar tog besliste tendense en konvensies wat gelei het tot die ontstaan van in normale woordorde $(1975: 248)$. Schwyzer kom ook tot die konklusie dat "Wortfolge gehort zu den Spracherscheinungen auf der Grenze zwischen Syntax und Stilistik" (1950:690). 
Dit bly wel 'n vraag in hoe ' $n$ mate stylfigure op woordorde 'n invloed uitoefen. Jordaan noem 'n hele aantal stylfigure wat volgens hom geen invloed op woordorde uitoefen nie $(1978 ; 66-70)$.

"Style involves the way in which something is said and therefore one should judge an author's style on all levels of expression: the word, the phrase, the sentence, the paragraph, and so forth - in short, the style of the discourse" (Louw, 1985:173). Woordorde, frekwensie van woordgebruik, weglating, herhaling van woorde, stylfigure en dan alles in die breër raamwerk van die perikoop of die redevoering is van belang by stilistiese analise van Nuwe-Testamentiese tekste.

$$
\text { - }
$$

\section{STILISTIESE ANALISES}

\section{1 MARKUS 8:38}

Ons gaan eers kyk na 'n teks uit Markus. Die styl lyk redelik eenvoudig. Dit is egter interessant om op te merk dat verskillende kommentatore verskillende stilistiese verskynsels op die mikrovlak van hierdie gedeelte van Markus aangewys het. J.L. Venter het in Mk 8:38 'n chiastiese patroon opgemerk wat volgens hom 'n belangrike identifikasie openbaar:

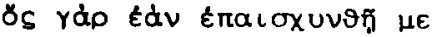

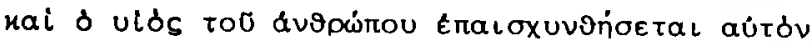
$\mathbf{b}^{1}$

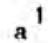

In die chiasme $a b-b^{1} a^{1}$ is $a-a^{1}$ telkens dieselfde persoon en bestaan daar dus ten opsigte van $b-b^{\prime}$ 'n referensiële identiteit. Dit lei tot die uiters belangrike beklemtoning deur middel van die chiasme, naamlik dat Jesus identies is met die Seun van die mens (Venter, 1983:42).

Van der Walt het in Mk 8:38 die stylfiguur van die antitetiese parallelisme ontdek. Hy ag hierdie stylfiguur besonder belangrik, omdat dit ons kan help om 'n antwoord te vind op die vraag hoe ons die uitdrukking: In die heerlikheid moet verklaar. Dit hang saam met die probleem van die $-382-$ 
koms van die Seun van die mens. Die algemene verklaring is dat die Menseseun tweemaal kom: eers om te ly en te sterf en daarna as Regterkoning om te oordeel. Van der Walt is egter van oordeel dat die Menseseun driemaal kom: die eerste keer veral om te sterf, die derde keer as Regterkoning en tussen die twee as skeiding en as verbinding SY koms in heerlikheid. Hierdie tweede koms mag egter nie sonder meer as in derde koms op dieselfde vlak naas die twee ander komste gestel word nie (Van der Walt, 1962:78). Die vraag is hier of ons die frase en te doxe modaa! moet verklaar: Jesus kom met heerlikheid, of dat ons dit lokaal moet verklaar: Jesus kom in heerlikheid, in die heerlikheid van sy Vader. As hierdie vers op die wederkoms van Christus en op die laaste oordeel sou slaan, dan sou die uitdrukking en te doxe modaal verklaar moes word: Jesus kom met heerlikheidsverskyning. In die bywoordelike frase wat hiermee korrespondeer en te geneia taute is die preposisie en duidelik lokaal.

Mk 8:38 vertoon die struktuur van in antitetiese parallelisme:

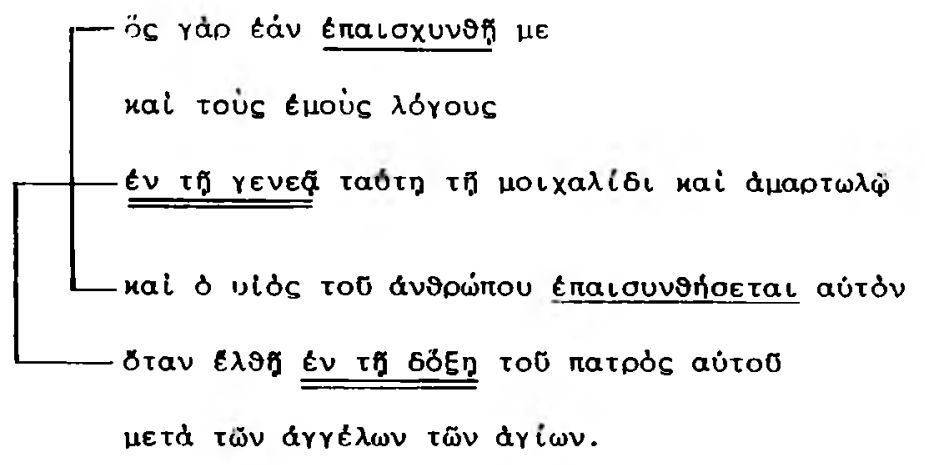

Wanneer en te doxe modaal verklaar sou word, is daar volgens Van der Walt nie alleen in sintaktiese verskil nie waar die en-frase in die eerste lid van hierdie parallelisme op in bepaalde bedeling slaan en die tweede lid beperk word tot in bepaalde gebeurtenis, naanlik die van wederkoms en oordeel, maar dan is ook die noukeurig opgeboude parallelisme versteur. Van der Walt is van oordeel dat ons by die verklaring van Mk 8:38 terdeë rekening moet hou met die stylfiguur wat in die teks te vinde is (Van der Walt, 1962:73). Hy is oorluig dat en te doxé slaan -383- 
op die heerlikheid(-bedeling) wartoe die Seun van die mens met sy lyde, dood en opstanding toetree, terwyl hotan elthe hierdie oorgang aandui. Die konstruksie elthein en in die sin van "kom in, toetree tot" mag vreemd klink, maar die Koine-Grieks onderskei nie so skerp tussen en en eis nie. Van der Walt wil egter by die verklaring van hierdie teks nie alleen rekening hou met die stylfiguur van die antitetiese parallelisme nie, maar ook die hele perikoop laat meespreek. Hy sien twee motiewe wat sterk in die hele betoog funksioneer: een motief wat meer op die horisontale vlak beweeg met as pole lyde en heerlikheid, verlies en wins, vernedering en verhoging, en 'n tweede motief wat op die vertikale vlak beweeg met as pole die "aardse" en die "hemelse", die "diesseitige" en die "jenseitige", miskien hierdie bedeling en die komende bedeling (Van der Walt, 1962:73).

In Mk 8:38 kry ons dan die fundering - steeds antiteties-parallel - in die korrelasie tussen die optrede van die mens in sy 'sfeer' teenoor die Seun van die mens, én die optrede van die Seun van die mens in sy 'sfeer' teenoor die mens (Van der Walt, 1962:74).

W.S. Vorster is van oordeel dat Van der Walt ten onregte die klem op die frase en te doxe laat val, omdat hy die uitdrukking foutiewelik formeel as antiteties parallel met en te genea taute beskou (Vorster, 1979:190). Volgens Vorster word die preposisie en sintakties saam met doxe ktl. groepeer en die uitdrukking dui die wyse aan warop die Seun van die mens met die oog op die gerig sal kom (1979:190). Vorster kies dus vir die modale verklaring, terwyl hy tog later die volle segging van die en doxe-frase vertolk as: Die Seun van die mens kom in die heerlikheid van sy Vader! (Vorster, 1979:190).

G. Sevenster kies ook vir die lokale verklaring. Hy dui Jesus aan as die 'troongenoot' van God wat "de bestemming heeft, een kring van "heiligen" om zich te vormen" (1946:86). E. Schweizer beskou hierdie logion van Jesus as 'n toevoeging van die vroeë kerk. In hierdie teks word Vader, Seun en engele bymekar gebring soos ons dit ook vind in 1 Tm 5:21 en 1 Ts 3:13. Hy beskou dit as "typical of a church which has an apocalyptic orientation" (1971:178). In sy vertaling kies Schweizer ook vir die lokale verklaring. 
Wanneer ons die vertaling van 1933 van die Afrikaanse Bybel vergelyk met die vertaling van 1983 dan sal ons sien dat die 1933-vertaling die lokale verklaring gee, terwyl die 1983-vertaling gekies het vir die modale verklaring met nog die byvoeging van die woord "dieselfde". Jesus is beklee met "dieselfde" heerlikheid.

\section{2 JOHANNES $1: 29-34$}

In die kontrovers tussen die kerk en die Pinkstergroepe en die Charismatiese Beweging kom telkens die vraag na vore wat die Bybel presies bedoel met die doop met die Heilige Gees. Val die doop met of in die Heilige Gees saam met die wedergeboorte, die begin van die nuwe lewe soos in die kerke verkondig word of is dit ' $n$ tweede daad van God ná die bekering. 'n "second blessing", 'n opvolgaksie van God om die gelowiges toe te rus vir hulle diens wartoe hulle geroep is?

Soms is dit besonder moeilik om selfs na noukeurige eksegese van 'n teks duidelik vas te stel wat die regte betekenis van daardie betrokke Skrifwoord is. Dit is met name die geval met Jh 1:33 waaroor die doop met die Heilige Gees gespreek word. In so 'n geval kan stilistiese analise van die teks en ook van die perikoop help om tot die regte verklaring van die teks te kom. Wanneer ons 'n struktuuranalise maak van die perikoop warin die bekende teks oor die doop met die Heilige Gees voorkom, dan kry ons die volgende beeld: 


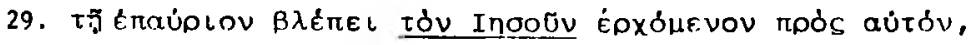
Kai $\lambda \hat{E} Y \in l$
A. “I IE ó duvòs too $\theta \varepsilon O 0$
B. $\quad$ a a

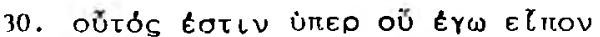

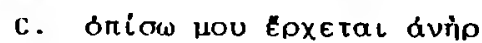

ôs Eumpoơév hou Yérovev,

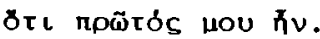

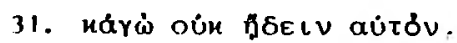

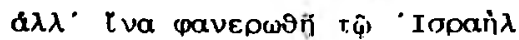

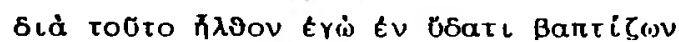

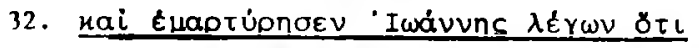

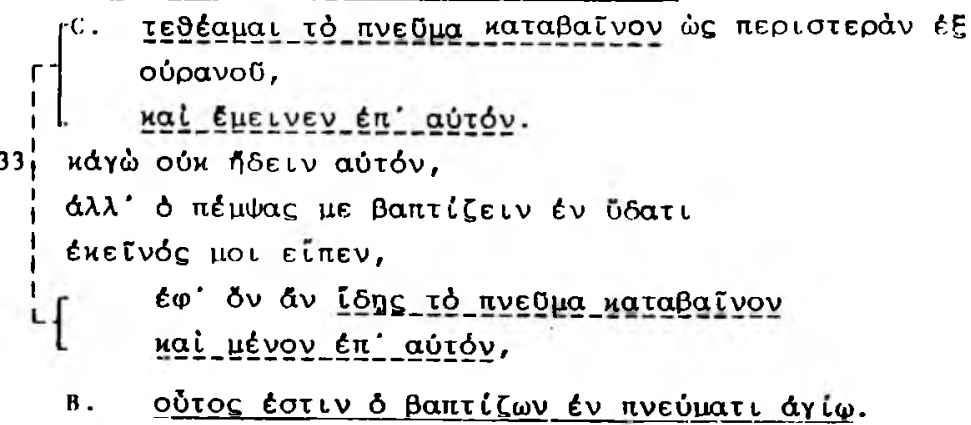

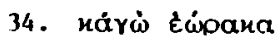

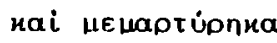

A. Śtl oũtos totlv ò vióc tô geou.

Hierdie perikoop vertoon die tipiese styl van Johannes. Daar is herhaling en progressie in dip struktuur. Eers verklaar die skrywer dat Johannes die Doper iets sé (legnj) in vs. 29. Daarna intensiveer die spreke van Johannes die Doper deur dit te onskryf as 'n getuienis (emarturesen) in v5. 32. Vervolgens keer hy die volgorde van sy betoog om, wardeur die geheel die struktuur vertoon van 'n ringkomposisie met behulp van 'n chiasme: A - B - C - C - B - A. Eers beskryf Johannes Jesus as die l.am van God. Hy gee daarmee 'n bepaalde beskrywing van sy persoon. Hierdie uitspraak word gevolg deur 'n kwalifikasie van sy werk: Hy gaan die sonde van die wèreld wegneem. Aan die einde van -386 - 
die hele betoog word weer ' $n$ beskrywing van Jesus se werk gegee en dan sluit die perikoop af met 'n tweede beskrywing van sy persoon. Die skrywer trek op hierdie wyse die aandag van sy lesers op hierdie twee-maal-twee-is-vier-fokuspunte. Wanneer ons die vier-fokuspunte uitlig, kry ons die volgende beeld:

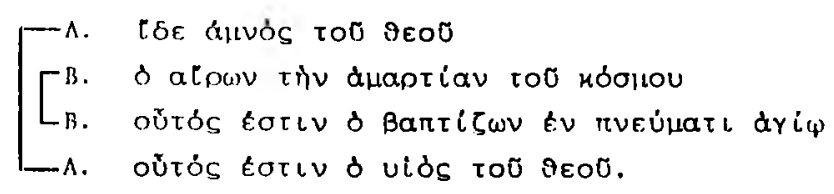

Uit hierdie chiastiese opbou van die perikoop kan ons aflei dat die begrip Lam van God met die uitdrukking Seun van God korrespondeer en dat daar ook ' $n$ verband is tussen die wegreem van die sonde en die doop met die Heilige Gees. Soos die Lam van God nie van die Seun van God geskei kan word nie, so mag ons die doop met die Heilige Gees nie van die wegneem van die sonde losmaak nie. Die doop van Jesus is onlosmaaklik verbonde met die afwas van die sonde en die wegneem van die sonde. Ons kan op grond van 'n stilistiese analise van hierdie perikoon die doop met die Heilige Gees deur Jesus dan ook aandui as "geven van nieuw leven door vergeving van zonden" (Du Plessis, 1978: 132, 133). Dat daar inderdaad met name in die evangelie volgens Johannes 'n innige samehang is tussen die doop met die Heilige Gees en die vergewing van sonder blyk ook duidelik uit Jh 20:22,23. Ons vind daar 'n Johanneïese beskrywing van Pinkster. Jesus blaas op sy dissipels en sê vir hulle: "Ontvang die Heilige Gees." Dadelik daarna vervolg Jesus: "As julle die mense hulle sondes vergewe, dan word dit vergewe; as julle die mense hulle sondes hou, dan is dit gehou." Johannes wys in sy evangelieverliaal op die nou band tussen Jesus, die lleilige Gees en die vergewing van sondes tot n nuwe lewe (Du Plessis, 1978:136). In die raamwerk warbinne Johamnes die doop met die Heilige Gees ter sprake bring, is daar nie aanleiding on by die doop met die Heilige Gees te dink aan in tweede daad van die Gees wat losstaan van die werk van die Gees in wedergeboorte en bekering nie.

\subsection{ROMEINE 11:6-9}


In Rm 14:1-12 kom die apostel Paulus met 'n sesvoudige vermaning. In hierdie perikoop is daar duidelik 'n stygende patroon, wat soos volg weergegee kan word:

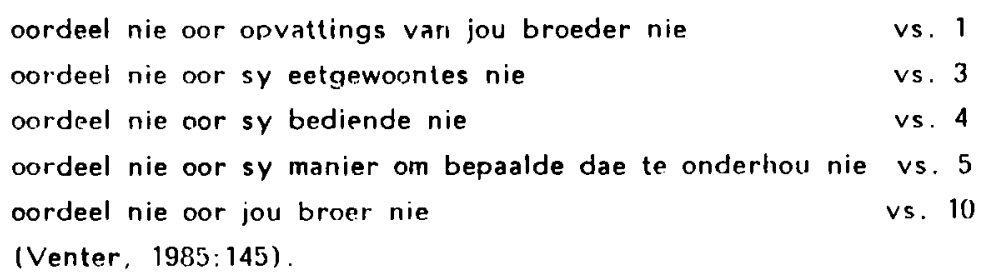

Die lyr loop vanaf oordeel oor opvattings in verband met eet of nie ent nie, in onderhouding of nie van sekere dae, tot by die uiterste: die oordeel oor jou broeder. Dit is besonder belangrik om daarop te let op watter wyse Paulus in hierdie perikoop sy paraenese fundeer. Hy doen dit in die verse 7 tot en met 9. Die struktuur lyk soos volg: - poovav inv h̀uépav kupip poo vei

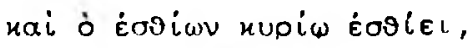

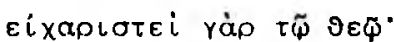

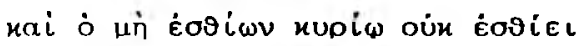

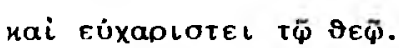

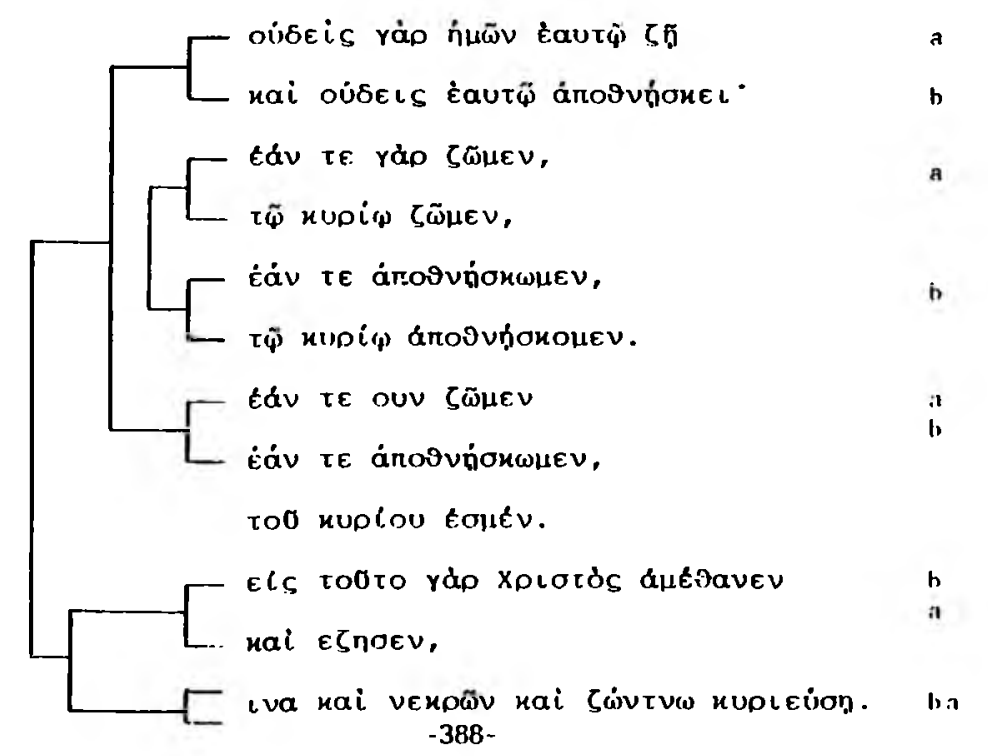


In die verse 7 tot en met 9 gee die apostel die grond vir die voorafgaande paranese met in sterk a-b-a-b-opbou. Die parallelle opbou wat konsekwent gefunksioneer het in die volgorde lewe (a) en dood (b), word dan eensklaps in vs. 9 ongekeer in dic patroon b-a: Christus het gesterwe (b) en (begin: ingressiewe aoristus) lewe (a). Die feit dat die gelowige in lewe en in sterwe (a-b) aan Christus behoort, moet gegrond word in die omgekeerde volgorde by Christus, naamlik sterwe en lewe (b-a). Dieselfde patronn van b-a word dan voortgesit in die slot van vs. 9: Jesus regeer as Kurios (kurieusen) oor dooies (b) en lewendes (a).

Hierdie omgekeerde patroon in die fundering van die vermaninge gee ' $n$ besondere nuanse aan die paraenese. "Christus, Heerskappyvoerder, hét gesterf, hét opgestaan, daarom kan die gemeente vermaan word om mekaar in ag te neem - en daarom kan die gemeente die vermaning gehoorsaam" (Venter, 1985:144).

\subsection{DIE BRIEF VAN JUDAS}

\subsubsection{Die styl van die Judasbrief}

Alvorens ons gaan kyk na die struktuur en die styl van 'n klein onderdeel van hierdie brief, sal daar eers aandag gegee moet word aan die brief in sy geheel. Hierdie klein briefie iewers in 'n uithoek van die Nuwe Testament het nie altyd die andag gekry wat dit verdien nie. D.G. Breed het opgemerk dat uit die literatuur wat oor hierdie brief beskikbaar is, dit blyk dat kommentatore maar weinig aandag gegee het aan die sentrale tema van die Judasbrief en tog ag hy dit belangrik vir die interpretasie en evaluering van moeilike grdeeltes in die brief (Breed, $1981: 7)$.

in fiedaglestruktuurontleding volgens die metode van J.C. Coetzee (1980:7-13) het die volgende natroon an die lig gebring: 


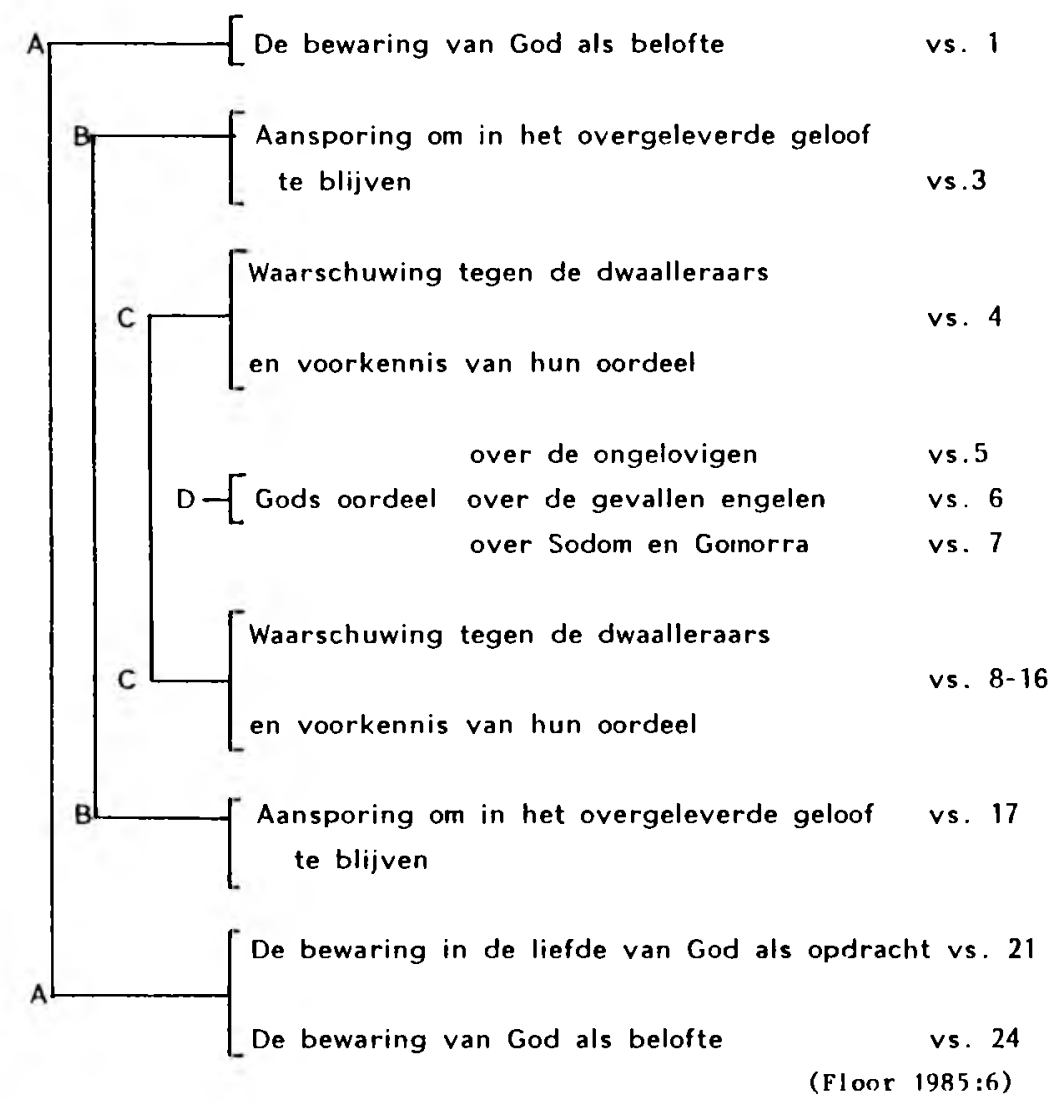

Die struktuur van hierdie brief is ' $n$ ringkomposisie: $A$ - B - C - D C - B - A. Wanneer ons kyk na die buitenste sirkel (A-A) dat ontdek ons daar die bewaringsmotief. Die tweede sirkel (B-B) is in aansporing om in die oorgelewerde geloof, die fides quae creditur te bly. Die oorgelewerde geloof (vs. 3) is dieselfde as die woorde wat deur die apostels gespreek is, die mondelinge oorlewering (vs. 17). 'n Derde, kleiner ring $(\mathrm{C}-\mathrm{C})$ is die warskuwing teen die dwaalleraars en die goddelike voorkennis van hulle oordeel (vs. 4,15,17). Die drie ringe is gegroepeer rondom die sentrum van die brief waar die oordeelsmotief na vore kom: God se oordeel oor die ongelowiges, oor die gevalle engele en oor die bewoners van Sodom en Gomorra (vs. 5,6,7). Wanneer Judas in die middelstuk van sy brief (vs. 8-16) God se oordeel oor die 
dwaalleraars verder uitwerk dan vind ons in hierdie gedeelte ook weer 'n bepaalde patroon:

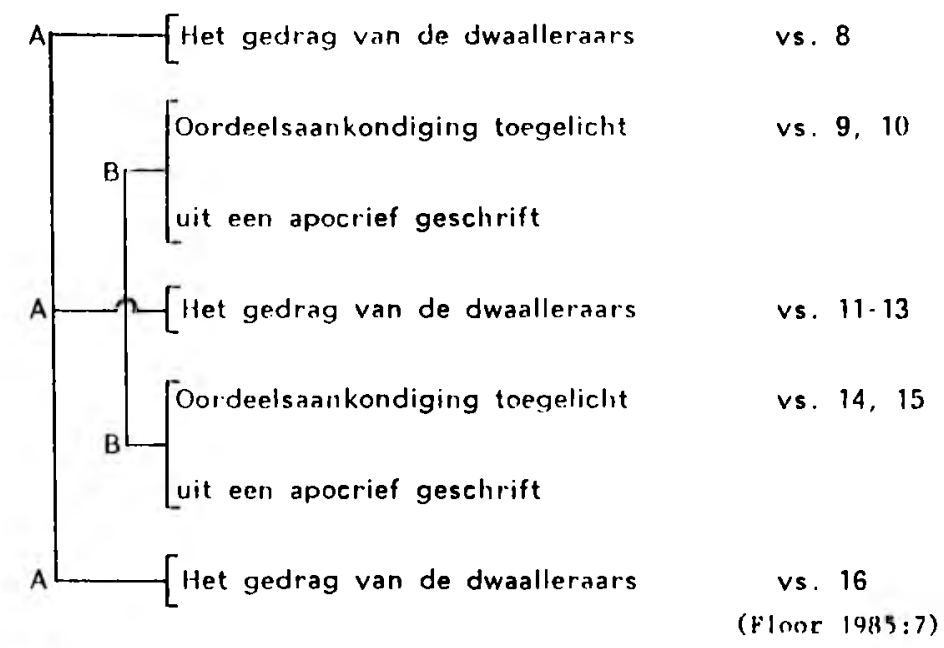

Dit moet ons tref dat die gedagtes in die Judasbrief uiters sorgvuldig gerangskik is. In die strukturele opbou van hierdie brief is daar 'n veelvuldige gebruik van die getal drie.

In sy openingsadres rig die skrywer hom tot hulle wat deur die Vader geroep is, wat Hy liefhet en wat deur Jesus Christus bewaar word. Driemaal spreek Judas sy lesers aan as geliefdes (vs. 3,17,20). Driekeer klink die bewaringsmotief: die gelowiges word in die liefde bewar (vs. 1), die gevalle engele word vir die oordeel bewar (vs. 6) en die dwaalleraars word vir dic ewige duisternis bewaar (vs. 13). Ook hoor ons driekeer die verlossingsmotiel: God het sy volk uit Egipte verlos (vs. 5), hulle wat twyfel moet uit die vuur verlos word (vs. 23) en God word die Verlosser genoem (vs. 25).

Op grond van die struktuur van hierdie pragtig npgeboude brief kan die kerrinlioud soos volg geformuleer word: laat $u$ in lielde bewaar deur God wat u bewaar

D.G. Breed, wat in indringende analise van die Judasbrief gedoen het volgens die sintaktiese struktuurontledingsmetode van Fika van Rensburg 
en volgens die metode van gedagtestruktuurontleding van J.C. Coetzee, kom tot die volgende hooftema van hierdie brief: God die Vader het julle vir Jesus Christus bewaar; bewar julleself daarom in sy liefde (lewe in sy liefde) en stry teen die dwalleraars en hulle dwalinge deur julle op te bou in die allerheiligste geloof (waarheid van die geloof), voortdurend in die Heilige Gees te bid (' $n$ heilige lewe) en die barmhartigheid van ons Here Jesus Christus tot die ewige lewe te verwag. Stry, want God se oordeel oor die dwaalleraars is vas en seker (Breed, 1981:73,74).

Michael Green kom tot 'n soortgelyke samevatting van die brief van Judas wanneer hy ook die bewaringsmotief uitlig: "It is God's part to keep man; but it is man's part to keep himself in the love of God. These are the two sides of Christian Perseverance (of Phil. ii, 12,13)" (Green, $1976: 156,157)$.

Oor die styl van Judas se brief kan baie opmerkings gemaak word Turner is veral getref deur die uitsonderlike woordeskat van hierdie brief (1976:144). Baie van Judas se frases "have a poetic ring about them", so skrywe Bigg (1901:322). Wanneer ons die styl van die Judasbrief gaan toets aan die vier basiese stylsoorte wat die Griekse retorikus Demetrius onderskei, naamlik eenvoudige styl, kragtige styl, uitgebreide styl en elegante styl, dan kan Judas se styl sonder veel moeite as kragtig bestempel word (vgl. Cronjé, 1982:14). Die kragtige styl word aangewend wanneer sterk emosies ter sprake kom of wanneer die spreker of skrywer iemand wil kritiseer.

D. Rowston het in sy studie: "The setting of the letter of Jude" in indringende analise gemaak van die styl van die Judasbrief Hy noem drie karakteristieke eienskappe wat hierdie brief vertoon. In die eerste plek het Judas die tradisionele bronne waruit hy veelvuldig aanhaal op 'n eie karakterristieke manier aangewend. Judas gebruik daardie aanhalings telkens op kritieke punte wanneer hy sy opponente wil aanval (Rowston, 1971:90).

In die tweede plek is dit ook karakteristiek van Judas dat hy in sy eksplosiewe brief gebruik maak van die sogenaamde herinneringsmotief. Onthou Israel se reis deur die woestyn (vs. 5), onthou die rewolusie van die engele (vs. 6), onthou God se oordeel oor Sodom en Gomorra (vs. 
7), maar onthou ook die apostoliese oorlewering (vs. 17). Hierdie aanhalings was voldoende "to evoke a knowing response from the original readers" (Rowston, 1971:92).

'n Derde karakteristieke eienskap van die brief van Judas is die aanwending van trefwoorde soos goddeloos (vss. 4,15,18), murmureerders (vs. 16) en skeurmakers (vs. 19). Judas gebruik hierdie trefwoorde as "sloganeering ammunition" (Rowston, 1971:96). Onder hierdie trefwoorde val ook die interessante verskynsel dat Judas sy lesers telkens aanspreek as agapetol, gelieldes (vss. 3,17.20) en daar teenoor sy teenstanders as nontoi, hierdie mense (vss. 8, 10, 14, 16,19).

\subsubsection{Judas: 20,21}

Wanneer ons vervolgens twee tekste uit die brief van Judas uitlig. naamlik die paraenese in verse 20 en 21 . Iyk die sintaktiese analise soos volg:

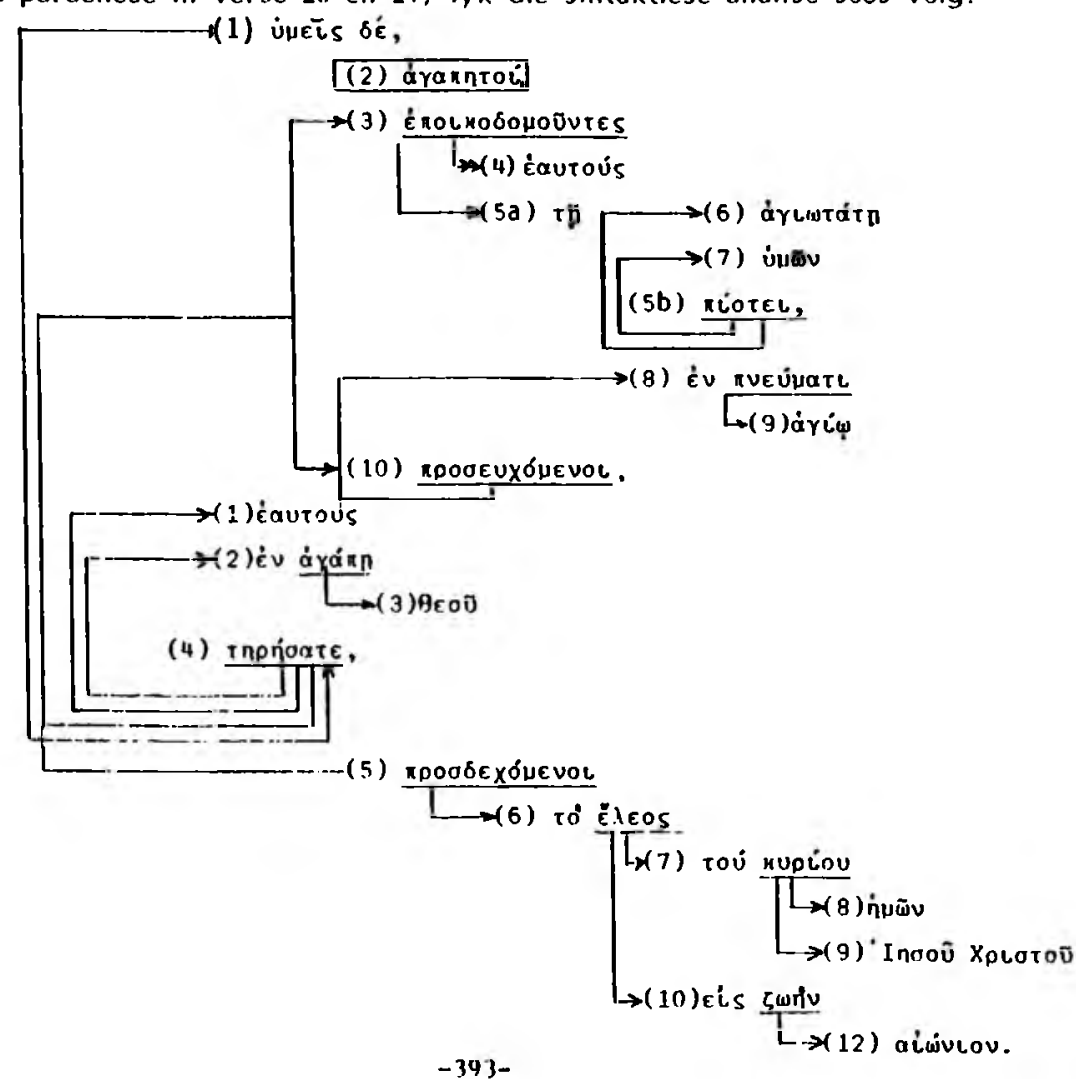


Die voegwoord de aan die begin van vs. 20 is 'n sintaktiese merker met in neweskikkende teenstellende funksie. As opvallende sintaktiese verskynsels kan genoem word dat hierdie eenheid uit drie kola bestaan, te wete twee deelwoordírases, 'n imperatief en dan weer 'n deelwoordfrase (Breed, 1981:29).

Die vraag is of die drie deelwoordfrases met die imperatief verbind moet word en wat dit beteken vir die verklaring van die teks.

Daar is vervolgens twee paaie wat ons kan bewandel. Ons kan die sinne opdeel in hulle nuklére strukture en hulle dan lys, of ons kan in gedagtestruktuurontleding doen. By die eerste metode moet ons gaan soek na die gebeure, die kerndele waaromheen 'n sin ontwikkel. Dan moet die progressie in die perikoop beskryf word in terme van die logiese relasies tussen die nuklére strukture met verwysing ook na relasies tussen groter eenhede.

Met hierdie metode kan ons ongetwyfeld algemene stilistiese gegewens identifiseer, maar daar is nog nie aangetoon dat hierdie metode vir die beter verstaan van 'n teks ook 'n bydrae kan lewer nie. Voorlopig word dus maar die metode van gedagtestruktuurontleding gevolg. Die gedagtestruktuur lyk soos volg:

ÜHeโs $\delta t$, áyanntoi

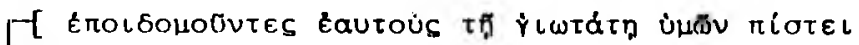

- É Eveúhat l dYlф noooeuXóhevol

$\exists$ Eautoùs $\varepsilon v$ arám $9 \varepsilon o \sigma$ tnprioare

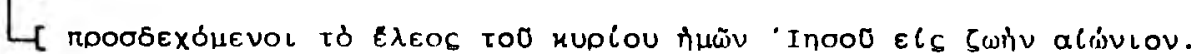

Daar is in hierdie verse in duidelike trinitariese opbou: die liefde van God, die gebed in die Gees en die verwagting van die wederkoms van Christus. Trefwoorde is hier geloof, gebed en hoop. Die drieslag geloof, liefde en hoop met hoop as laaste in in klimaktiese posisie wat die hele perikoop sterk op die wederkoms rig. herinner aan Paulus en kan wys op Pauliniese invloed by die skrywer (De Klerk, 1983:344; Rowston, $1971: 94)$ 
Kernmoment in die perikoop is die paraenese: bewaar julleself in die liefde van God. Die werkwoord terein, "bewaar", wat oor die hele brief verspreid voorkom, beklee in belangrike plek in die sentrale boodskap van Judas. Uit die struktuuranalise van die hele brief het reeds geblyk dat die bewaarmotief aan die begin deur Judas as ' $n$ belofte aangedui word. Hier keer die motief terug as 'n bevel. Die twee aansporings in vs. 3 en vs. 17 om in die oorgelewerde geloof te bly, vind sy kulminasiepunt in die opdrag om hulleself in die liefde van God te bewaar. Met liefde van God bedoel Judas in die eerste plek liefde wat van God uitgaan, die genitief is dus 'n subjektiewe genitief. Maar die liefde tot God, dan is die genitief 'n objektiewe genitief, is beslis nie uitgesluit nie.

Kommentators het nogal probleme met die verklaring van die paraenese: bewaar julleself in die liefde van God. Die een sé die gelowiges moet die liefde-relasie met God kultiveer (Green, 1976:185). 'n Ander beweer dat dit gedoen moet word deur die gebooie van God te bewar (Greijdanus, 1929:646). 'n Derde ag dat die gelowiges hulleself veilig moet bewaar in die verbond deur gehoorsaamheid (Bigg, 1901:340).

Die antwoord op die vraag wat die paraenese beteken, moet in die perikoop gesoek word. Die struktuur kan ons hier help. Die imperatief stel vir die lesers die dat van die bewaring in die liefde van God, terwyl die deelwoorde wat noul met die imperatief gekoppel is die hoe van die bewaring aandui. Die bewaring in die liefde van God geskied deur drie dinge: deur die selfopbou in die geloof, deur die gebed in die Gees en deur die verwagtende uitsien na die wederkoms van Jesus Christus.

Wat in die drie deelwoorde gestel word, is "bepalingen, die manieren, omstandigheden en middelen noemen, hoe en onder en door welke deze zelfbewaring in de liefde Gods geschieden moet" (Greijdanus, 1929:646).

'n Volgende vraag is wat die skrywer met die selfopbou in die geloof bedoel. Die werkwoord het twee betekenisvlakke: "staan op" en "hoër oprys". Met geloof bedoel Judas hier die fides qua creditur, die geloof as instrument. Geloofsopbou ag Judas baie belangrik, want dit immuniseer teen die dwaalleer. Opbou is in die Nuwe Testament in 
"pneumatische begrip, dat de noodzakelijke groeiende toenadering tot Christus aanduidt" (Bolkestein, 1972:231).

Konsentrasie op Christus: Judas noem dit die barmhartigheid van ons Here Jesus Christus tot die ewige lewe. Hierdie uitdrukking het 'n sterk eskatologiese spits. Prakties moet dit beoefen word deur middel van die gebed. Daarom spreek Judas van die noodsaaklikheid van die gebed in die Gees. Hiermee bedoel hy 'n gebed onder die heerskappy, die gesag van die Heilige Gees. Die dwaalleraars kan so nie bid nie, want hulle het nie die Heilige Gees nie (vs. 19). Die gebed in die Gees is nie 'n glossolale gebed nie, maar veeleer 'n lofprysende gebed warvan Judas in pragtige voorbeeld gee in sy doksologie (vss. 24,25) wat qua styl en segging, innerlike majesteit en verhewenheid tot die uitnemendste in sy soort in die Nuwe Testament behoort (Wohlenberg, 1923:332). In Judas se doksologie keer die bewaringsmotief terug. Die tema van die hele brief word met 'n sterker werkwoord as tere in tot uitdrukking gebring. Judas gebruik hier die woord fulassein: "aan Hom wat magtig is om julle te bewaar". Die doel van die goddelike bewaring word deur Judas omskryf met die uitdrukking: stesai katenopion tes doxes: "om julle voor die aangesig van sy heerlikheid te stel". Daarom moet die doxa, die heerlikheid van God geprys word. Judas doen dit met 'n opeenstapeling van al magskategorieë. Die God wat ons vir Jesus Christus bewaar en wat ons geroep om onsself in sy liefde te bewaar, is lofwardig, nou en tot in alle ewigheid.

\section{BIBLIOGRAFIE}

ATKINS, J.W.H. 1952. Literary criticism in Antulquity. A sketch of its development Vol II, Greaco-Roman. London.

BETZ, H.D. 1974-5. "The literary composition and function of Paul's letter to the Galatians" in New Testament Studies 21(1974-5).

BIGG, C. 1901. A Critical and exegetical commentary on the Epistoles of St. Peter and St. Jude. Edinburgh: $T \& T$ Clark.

BOLKESTEIN, M.H. 1972. De brieven van Petrus en Judas. Nijkerk. 
BOTHA, J. 1984. 'n Stilistfese Analise van dle Christushimme (Kol 1:15-20). Werkstuk voorgelè in vierde studiejaar vir die Th.B.-graad, PU vir CHO, Potchefstroom.

BREED, D.G. 1981. Dle sentrale tema van die Judasbrief. 'n Eksegetiese studie. Werkstuk voorgelè in die vierde studiejaar vir die Th.B.-graad, PU vir CHO, Potchefstroom.

BROWN, R. 1968. Style and r.anguage, (red. T.A. Sebeok), Cambridge.

CLARK, D.L. 1959. Rhetoric in Greco-Roman Education. New York.

CIIURCH, F.F. 1978. Rhetorical structure and design in Paul's letter to Philemon, Harvard Theological Revinw 71.

CRONJE, J.v.W. 1982. Demetrius on forcible style. Ongepubliseerde referaat gelewer op 'n seminaar oor styl, Universiteit van Pretoria.

COETZEE, J.C. 1980. Die gedagtestruktuur van 2 Johanips. 'n Illustrasie van die belangrikheid van struktumrontleding vir die interpretaste en prediking van die Nuwe Testament. Wetenskaplike bydraes van die PU vir CHO. Reeks A: Geesteswetenskappe, nr. 26, Potchefstroom.

DE KLERK, B.J. 1983. Die gesag van die predlking van die Nuwe-Testament tese brlewn, Potchefstroom.

DU PLESSIS, P.J. 1978. Zie het Lam Gods. Overwegingen bij de knechtsgestalte in het evangelie van Johannes, in: De knechtsgestalte van Christus, studies aangeboden aan prof. dr. H.N. Ridderbos, Kampen.

FLOOR, L. 1985. Leer en leven. Enkele overwegingen over de brief van Judas, in: Theologia Reforinata, Jaargang XXVIII - No 3 Sept.

FUNK, R.W. 1961. A Greak Grammar of the New Testament and Other Early Christian litterature, Chicago. 
GREEN, M. 1976. The Second Epistle of Peter and the Epistle of Jude. Grand Rapids.

GREIJDANUS, S. 1929. De Brieven van de apostelen Petrus en Johannes, en de brief vail Judas. Amsterdam.

GRUBE, G.M.A. 1961. A Greek Critic: Demetrius on style. Toronto.

JORDAAN, G.J.C. 1978. Woordorde-variante in die manuskripte van die Griekse Nuwe Testament. Potchefstroom.

KENNEDY, G. 1963. The Art of Persuasion in Greece, Princeton.

HALLIDAY, M.A.K., and HASAN, R. 1976. Cohesion in English, London.

LATEGAN, B.C. 1984. Galasiërs, in: Du Toit, A.B. (red) llandleiding by die Nuwe Testament, Pretoria.

LLOYD-JONES, D.M. 1976. Romans. Exposition of Chapter 5: Assurance. Edinburgh.

LOUW, J.P. 1967. St1listiese sinsboustrukture en Nuwe-Testamentiese Grinks. Bloemifontein: UOVS.

LOUW. J.P. 1975. Semantiek en Antieke Retoriek. Acta Classica 17.

LOUW, J.P. 1982. Rhetoric and style In ancient Greek education, with special emphasis on style. Unpublished paper read at a seminar on style, University of Pretoria.

LOUW, J.P. 1985. On Johannine Style. (Word gepubliseer in Neotest ament ica 19 ).

MOULTON, J.H. 1976. A Grammar of New Testament Greek. Edinburgh NIDA, E.A. ET AL. 1983. Style and discourse. Cape Town. 
ROWSTON, D. 1971. The setting of the letter of Jude. AnnArbor.

RADEMACHTER, L. 1911. Neutestamentliche Grammatik; das Griechisch des Neuen Testaments im Zusammernang mit der Volkssprache. Tübingen.

SCHENKEVELD, D.M. 1964. Studfes in Demetrius on style. AMsterdam.

SEVENSTER, G. 1946. De Christologie van het Nieuwe Testament. Amsterdam.

SCHWEIZER, E. 1971. The Good News according to Mark. London.

SCHWYZER, E. 1950. Grtechische Grammatlk auf der Grundlage von Karl Brugmanns Griechischer Grammat1k.

SNYMAN, A.H. 1982. Die betekenis van die stilistiese parallelismes in 1 Korintiërs 13. COngepubliseerde lesing by Departement Grieks, PU vir CHO). Potchefstroom.

SNYMAN, A.H. 1984. Style and meaning in Romans 8:31-39. Neotestamentica 18 .

TABER, C.R. 1985. Review NIDA, E.A. ET AI. Style and Discourse The Bible Translator Vol. $36 \mathrm{nr} 1$. Jan.

TURNER, N., VOL IV STYLE, OF MOULTON, J.H. 1976. A Grammar of New Testament Greek. Edinburgh.

ULLMANN, S. 1973. Menning and style. Oxford.

VAN DIJK, T.A. 1980. Story comprehension: an introduction, in: Poetics 9.

VAN DER WALT, Tj. 1962. Dle Koninkryk van God - naly! Kampen.

VENTER, C.J.H. 1985. Dip l'auliniese paraenese in Romeine 12:1-15:15, 'n eksegetjese studip. Potchefstroom. 
BENTER, J.L. 1983. Jesus se wonders in Markus 8 binne die geheelstruktuur van die hoofstuk. Pretoria.

VORSTER, W.S. 1979. AISCHUNOMAI en stamverwante woorde in die Nuwe Testament. Pretoria.

WOHLENBERG, G. 1923. Der erste und der zweite Petrusbrief und der Judasbrief. Leipzig.

SMIJEWSKI, J. 1978. Der stil der paulinischen "Narrenrede". Analise der Sprachgestaltung in 2 Kor 11, 1-12, 10 als Beltrag zur Methodik von Stiluntersuchnngen neutestamentliclier Texte. Köln-Bonn. 